た。また，作業は飲用前に 1 試行，领用後は 180 分目ま で 30 分ごとに 1 試行ずつ計 7 試行行なるせたが，作業 時間は 1 試行について 5 分間であり, 各試行の直前にフ リッカー値, 呼交フルコール量を測定し, 作業中は瞬目, 作業成績を連続的に測定・記録した。

結果软よび結諭：アルコール飲用による影響は呼気ア ルコール量, フリッカー低下率の增大, 瞬目パターンの 相違，トラッキングエラー減少の遅延，数字升別力の向 上，信号音弁別力の差としてそれぞれ示されて特り，二 重課題法を用いることによりアルコールの中枢影響をと らえることができたといえよう。

二重課題法法，作業負荷時の生理的心理的反応の研究 法として注目されたものであるといわれて物り，人間工 学の領域で疲労検査なぞに広く用いられている方法で㐫 る。しかし，この方法を中枢作用をるつ物質の影響評洒 のために応用することの可能性が本報告により示された ので，今後さらに湌討を加方，本法の有用性を発展させ てゆきたい。

\section{5. ラット度膚でのアルコール類の透過性について} 鶴田 筧 (産医研)

溶郕の皮䇠透過性とその物理化学的性質との間にはす で明らかにしたように踝水性溶剂化执いて皮膚透過速 度と水に対する溶解度との間に順相関が出り，未知の䠅 水性溶剂の皮覤透過速度を水汇対与る溶解剫から予知す ることが可能となった，そこで，今回は親水性溶剤での 皮膚透過速度を予知するための物理化学的指標につい て，手はじめとして正アルュール類について検討した。

溶剤の皮層透過速度の測定はすでに報告したラットの 摘出腹部皮膚を用いる拡散セル法により行なった。

8 種の正アルコール類の皮膚透過曲線はメタノールを 除〉之疎水性溶剂の場合之同様に lag phase の後汇定常 状態を示し，皮膚透過量淔線的に増大した。メタノー ルの皮盧透過曲線は lag phase の後 8 時間までしか定 常状態を示さず，皮㲊透過量は䅅布後 8 時間までは直線 的に增大したが，そる以後は增加量が徐々に小さくなっ た. 定常状態での皮虔透過速度 (nmoles $/ \mathrm{min} / \mathrm{cm}^{2}$ 皮 涌）はメタノールで 3,855 ，エタノールで 1, 460，プロ パノールで 1,196, ブタノールで 632 , ペソタノールで 174，へキサノールで 74.2, ヘプタノールで 20.9 , オク タノールで 4.33 となり，メタノールとオクタノールで は 890 倍の差がみられた。

皮虔透過速度 $\left(y \mathrm{nmoles} / \mathrm{min} / \mathrm{cm}^{2}\right.$ 皮有）之物理化学 的性質との関係では分子量 $(x)$ との間に $\log y=-0.029 x$ $+4.69, \gamma=-0.982$ の逆相関があり, 沸点 $\left(x^{\circ}\right)$ との 間には $\log x=-0.0213 x+5.06, \gamma=-0.983$ の逆相関
があり, 蒸気圧 $\left(x \mathrm{mmHg}, 25^{\circ}\right)$ との間には $\log y=$ $0.862 \log x+1.86, \gamma=0.986$ の順相関が友られた. 水に 対する溶解度との間化治一定の関係がなかったが，几キ サノール，ペンタノール，オクタノールなぞの溶解度の 小さいアルコール類で变束水性溶剂の場合に得られた相 関関係が適合した。 今後，このような相関関係がアセ卜 ン類やエステル類なぞの他の親水性溶剂ではどうである か登検討する予定である。

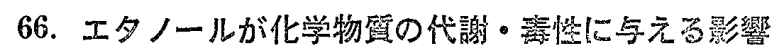
一栄養との関惪—

佐藤音夫，中島民江，小山 裕 村山忍三（信州大医衛生）

栄養との関連沈扮いて，ェタノールが化学物質の代謝 と毒性に与觉る影響を险討した。

[万法]標準，低脂肪，低炭水化物の 3 種の液体食を 調製し，さらに，扔の和の䬺にエタノールを加党，エタ ノールの 1 日揕取量が, $2.82 \mathrm{~g}$ (総摂取カロリーの $25 \%$ ) になるように液伶食を調製した。これら 6 種類の慨でラ ット（雄性 Wistar）を3週間飼育して実験に供した。 肝薬物代謝醭素活性は Sato \& Nakajima (1979) の方 法によった。

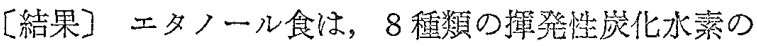
代謝速度を充進させたが，とくに低炭水化物食とともに

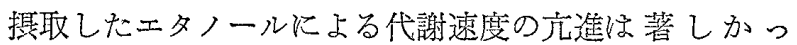
た.

低炭水化物食は，それ自身，藻物代謝酵复の活性学增 大させるが，エタノールの作用を著しく強めることがわ かった。また，低炭水化物食とともに与光られたェタ， 一ルはミクロゾーム蛋白とテトクロームP-450を增加さ 世たが，䈆水化物の多い慨とともに与光たェタノールで は增加が認められなかった。

次に，各群のラットに $200 \mathrm{ppm}$ の四塩化崖菜を 4 時 間暴露し，暴露直前・直後扐よび暴露開始 24 㭙間後の

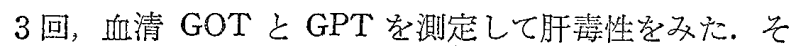
の結果, 低炭水化物食は, 父れ自身, 四塩化崖素の肝毒 性を增大さ好たが，低炭水化物食とともに与兄たエタ，

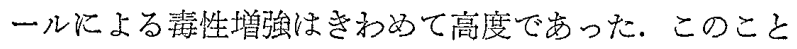
は, 暴露開始 24 時間後に屠殺して測定したミクロゾー ム蛋白とチトクロームP-450 が著明減少したことか らを明らかであった。

座長のまとめ $(64 \sim 66)$

広瀬 電（日清紡徳島）

この 3 題はアルコールに関するものである.

64：演者らは有機溶戍の中枢神経系化及ぼす影響をし らべるため，とトルアルコール领用の後，作業遂行能力 